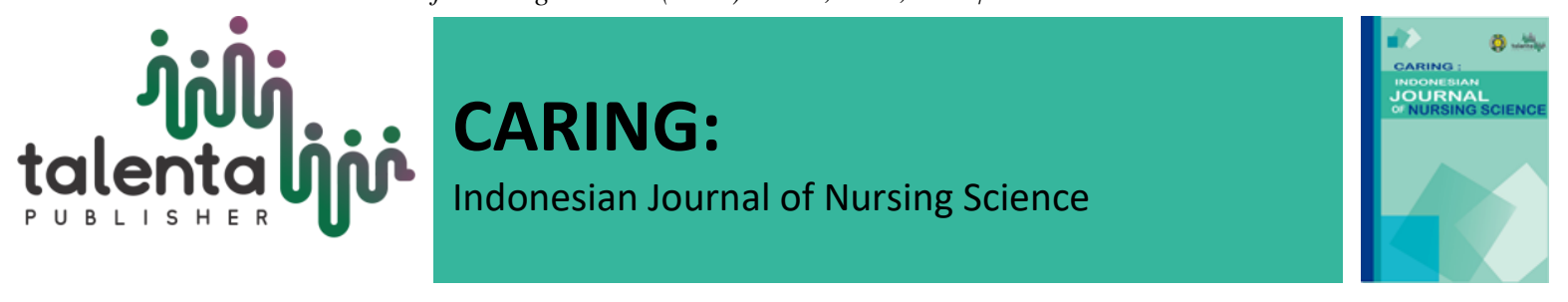

\title{
The Relationship on Social Support with Anxiety in Stroke Patients
}

\section{Wirda Faswita}

STIKes Sehat Binjai, Medan, Indonesia

\begin{abstract}
Around 90\% of patients having stroke experience sudden weakness or paralysis of the limb. Other signs and symptoms include memory problems and some signs indicating impaired brain function. This study aims to determine the relationship between social support and anxiety levels of stroke patients dependent on daily activities using a dynamic correlation research design. This study's data sources are primary data and secondary data using a questionnaire instrument and analysis using chi-square test. The analysis of social support with the anxiety level of stroke patients dependent on daily activities shows that the $\mathrm{p}$ value $=0.184$ ( $\mathrm{p}>0.05$ then Ho is rejected, and Ha is accepted). This means no relationship exists between social support and anxiety levels in stroke patients who experience dependency on daily activities at RSUD Dr. RM Djoelham Binjai.
\end{abstract}

Keywords: social support; stroke; anxiety

Received 30 ${ }^{\text {th }}$ March $2021 \mid$ Revised 6 $6^{\text {th }}$ July $2021 \mid$ Accepted 14 ${ }^{\text {th }}$ July 2021

*Corresponding author at: Jl. Gaperta Ujung, Tj. Gusta, Kec Medan Helvetia, Medan, Indonesia

E-mail address: wirdafaswita@gmail.com 


\section{Introduction}

Stroke is a disease attacking brain tissue caused by the reduced blood supply to the brain. This reduced blood and oxygen flow is caused by a blockage, narrowing, or rupture of the blood vessels in the brain (Shindy, 2014). In general, Stroke will cause depression, which means that the patient is aware of his condition and cannot carry out daily activities. Which causes problems that arise in stroke sufferers such as paralysis on one side of the body, decreased or loss of feeling, impaired visual field, impaired perception, emotional problems, and communication problems (Bintari, 2019)

Based on the result of Mustika's research (2019), it is stated that one-fifth to one-half of stroke sufferers experience a chronic disability resulting in hopelessness, feeling useless, no passion for life, accompanied by a decreased desire to talk, eat, and work. Nevertheless, $25 \%$ of them can work as before (Mustika, 2019). Feibel reported that one-third of 113 stroke survivors experienced depression or enormous pressure and would worsen. This is often found after six months to 2 years after a stroke (Hidayati, 2003). According to WHO (2010), there are 15 million people worldwide suffer a stroke every year. Among them, 5 million people die, and another 5 million people are experiencing permanent disability. In Indonesia, the number of stroke sufferers continues to increase.

Signs and symptoms of stroke may vary depending on the location and the extent of brain cell damage due to lack of oxygen supply. Stroke patients experience sudden paralysis, slurred speech, visual disturbances, dirty mouth, severe headache, vertigo, causing severe anxiety and depression. This anxiety and depression emerge as worries since stroke is a life-threatening disease to them (Mulyatsih, 2010). Social support has long-term consequences for physiological and psychological well-being and plays an important role during the patient's recovery from various illnesses (Cookson \& Casey, 2013). The research by Elloker and Rhoda (2018) found that high level of social support had a positive effect on patients' participation, social and recreational activities, and patients returning to work after stroke (Rhoda \& Elloker, 2018). The results of Mainoo Oyinlola Oluwagbemiga's (2017) found that social support interventions are best started early (at the diagnosis stage) and require continuous effort. Stroke patients need joint efforts from family support, financial support, emotional support, and friendly support (Blessing \& Oluwagbemiga, 2017).

\section{Research Method}

The study design used a cross-sectional approach, namely, to determine the relationship between social support and anxiety in stroke patients with dependence on daily activities within the working area of RSUD DR.RM Djoelham Binjai. This research was carried out at RSUD DR. RM. Djoelham, Binjai City. The reason is that when the researchers conducted the initial 
survey, there were 7 stroke respondents. 5 of them experienced anxiety causing dependence on daily activities.

This research was also carried out starting from November. In this study, the population was all stroke patients at DR. RM. Djoelham Binjai Hospital in February 2019, with a total of 25 people. The sample in this study uses an accidental sampling technique in which the technique of determining this sample is based on chance, namely anyone who is found by chance while researching throughout February 2019.

This research instrument can be a questionnaire (list of questions), observation forms, other forms related to data recording, and so on. For example, suppose the data to be collected is data related to physical examination. In that case, the research instruments are stethoscopes, tensimeters, scale, meter, or other anthropomorphic tools to measure nutritional status and so on (Notoatmojo, 2012).

Data collection in research sometimes does not only use one method of data collection. For example, in addition to the interview method (interview), sometimes it needs to be equipped with observations (observations), or vice versa. Likewise, the questionnaire method also sometimes needs to be equipped with interviews (Kosasih, 2018).

\section{A. Univariate Analysis}

This univariate analysis aims to explain or describe the characteristics of each research variable. The form of univariate analysis depends on the data type (Notoadmojo, 2010). In this study, the data that has been collected is processed by determining the answer scores from the questionnaire in which the value has been determined when the respondents answered 0 : strongly disagree, 1: disagree, 2: agree, 3: strongly agree, and 0: not at all, 1: little, 2: moderate, 3: severe, then the answer is compared with the number of questionnaires and the results are carried out $100 \%$ with the formula

$$
\begin{aligned}
& P=\frac{\sum f}{n} x 100 \% \\
& \text { keterangan: } \\
& \mathrm{P}: \text { respondent's answer percentage } \\
& \mathrm{N}: \text { respondent's answer total score } \\
& \mathrm{N}: \text { expected score }
\end{aligned}
$$

1. Social support

After the percentage is formed from each respondent, the final results of all respondents can be divided into two, namely:

1. Good: if the respondent answered correctly $>50 \%$

2. Less: if the respondent answered correctly $<50 \%$ 
2. Anxiety

After the percentage is formed from each respondent, the final results of all respondents can be divided into four categories, namely:

1. Mild: if the respondent answers correctly as many as 0-16 scores;

2. Moderate: if the respondent answers correctly as many as 17-33 scores;

3. Severe: if the respondent answers correctly as many as 34-48 scores;

4. Panic: if the respondent answers correctly as many as $\geq 49$ scores

Furthermore, the researchers entered the data into the SPSS application to identify the results of the respondent's data as a whole.

\section{B. Bivariate Analysis}

Bivariate analysis was carried out on two variables suspected to be related or correlated using statistical tests with chi-square test. If the p-value is smaller than alpha with a confidence level of $0.05(95 \%)$, Ha is accepted, and Ho is rejected. Thus, the hypothesis states a relationship between social support and anxiety levels of stroke patients dependent on daily activities at Dr. RM Djoelham Binjai in 2019 existed. On the other hand, the hypothesis will be rejected if the Pvalue is greater than alpha $(0.05$ or $95 \%)$. Thus, the hypothesis states no relationship between Social Support and Anxiety Levels of Stroke Patients Dependent on Daily Activities at Dr. RM Djoelham Binjai in 2019.

\section{Research Results}

\section{a. General Characteristics of Respondents}

From the study results of "Social Support with Anxiety Levels in Stroke Patients who are Dependent on Daily Activities at Dr. RM Djoelham Binjai Hospital in 2020," the respondents in this study amounted to 25 people were distributed based on age and gender.

Table1. General Characteristics of Respondents in the working area of RSUD. Dr. RM Djoelham Binjai

\begin{tabular}{llll}
\hline No & Characteristics Data & Frequency & Percentage \% \\
\hline 1. & Age & 15 people & $60 \%$ \\
& $50-55$ years & 10 people & $40 \%$ \\
& $56-60$ years & & \\
& & \\
2. & Gender & 6 people & $24 \%$ \\
& Female & 19 people & $76 \%$ \\
& Male & \\
3thnics & 10 people & $40 \%$ \\
& Java & 12 people & $48 \%$ \\
& Batak & 3 people & $12 \%$ \\
Malay & 25 people & $100 \%$ \\
\hline
\end{tabular}


Based on the table above, the majority data is people aged 50-55 years old (15 people), male (19 people), and part of Batak ethnic group (12 people).

\section{b. Univariate Analysis}

Table 2. Distribution Of Social Support with Anxiety in Stroke Patients

\begin{tabular}{lrrrrrc}
\hline & \multicolumn{5}{c}{ Anxiety } & Total \\
& & Mild & Moderate & Severe & Panic & \\
\hline Social Support & & & & & & \\
& Good & 0 & 2 & 15 & 1 & 18 \\
& Less & 0 & 3 & 4 & 0 & 7 \\
& Total & 0 & 5 & 19 & 1 & 25 \\
\hline
\end{tabular}

Social support with severe anxiety (15 people) was dominant at the good social support.

\section{c. Bivariate Analysis}

Table 3. Chi Square Test Result The Relationship of Social Support with Anxiety in Stroke Patients

\begin{tabular}{cccc}
\hline & Value & Df & Asymp.Sig. (2-sided) \\
\hline Person Chi Square & $3.383 \mathrm{a}$ & 2 & .184 \\
Likelihood Ratio & 3.361 & 2 & .186 \\
Linear-by-Linear & 3.140 & 1 & .076 \\
Association & & & \\
N of Valid Cases & 25 & & \\
\hline
\end{tabular}

Based on the table the value of the chi-quare person in the asymp.sign(2-sided) column which amounts to 0.184 with a value of $\mathrm{Df}=2$, then $\mathrm{Ho}$ is rejected and $\mathrm{Ha}$ is accepted. This means that there is no relationship between social support and anxiety levels in stroke patients who are dependent on daily activities at Dr. RM Djoelham Binjai Hospital in 2019.

\section{Research Discussion}

\section{a. Social Support}

Based on the research result above, most respondents have good social support, amounting to 18 respondents (72\%). In contrast, less social support amounts to 7 respondents (28\%). In this case, it shows that every individual experiencing problems in everyday life needs social support. It is a driving force to encourage people to do something to avoid failure in life (Donsu, 2017). Rook in Smeet said that social support is one of the functions of social bonds that describe the general quality level of interpersonal relationships. Bonding and friendship with other people are considered aspects that provide emotional satisfaction in an individual's life. When someone is supported by the environment, everything will feel more manageable. Social Support refers to interpersonal relationships that protect individuals against the negative consequences of stress. The received social support can make individuals calm, cared for, loved, confident, and competent. 


\section{b. Anxiety Levels}

Based on the study results above, it can be seen that the majority of respondents have severe anxiety levels, with a total of 19 respondents (76\%). In this case, the possibility of clients experiencing psychosocial stressors with anxious personalities who are more susceptible to suffering from anxiety disorders is more significant. Thus, the level of anxiety they experience is burdensome (Hawari, 2016).

According to Sarafino (1994), anxiety is a fear of one's powerlessness and response to an empty and meaningless life (Kosasih, 2018). Anxiety that occurs in stroke patients is caused by various neurological disorders such as motor loss in the form of hemipelgia (paralysis on one side) and hemiparesis (weakness on one side of the body), loss of communication, impaired perception, bladder dysfunction, impaired cognitive function and changes in brain function. psychology and the limitations in moving as a result of the illness he suffers. This condition is a cause of anxiety in stroke patients. Physical health is realized when a person no pain or no complaints Mental health includes a healthy mind, healthy emotional and spiritual health, while social health if someone able to interact with other people so that In the end, the patient can be productive in meaning to have activities that produce something that supports financially to his own life and that of his family (Widarti, et al., 2012). Based on research conducted by Ananda and Darliana (2017) the highest level of anxiety is moderate/severe anxiety with a total of 81 people (84.4\%) (Ananda \& Darliana, 2017).

\section{c. Social Support with Anxiety Levels}

From the results of the research above, $0(0 \%)$ respondents have "Good" social support with "Mild" anxiety level. 2 (0.8\%) respondents have "Good" social support with "Moderate" anxiety level. $15(60 \%)$ respondents have "Good" social support with "Severe" anxiety level, and 1 $(0.6 \%)$ respondent has "Good" social support with "Panic" anxiety level. From the table above, it can also be seen that $0(0 \%)$ respondents have "Less" social support with "Mild" anxiety level. $3(0.12 \%)$ respondents have "Less" social support with "Moderate" anxiety level. 4 (0.16\%) have "Less" social support with "Severe" anxiety level, and $0(0 \%)$ respondents have "Less" social support with "Panic" anxiety level.

The analysis result of the relationship between social support and anxiety levels on chi-square table above shows that chi-square person value in asymp.sign(2-sided) column is 0.184 , while $\mathrm{Df}=2$. Thus, Ho is rejected, and Ha is accepted. This means that there is no relationship between social support and anxiety levels on stroke patients' dependence on daily activities at Dr. RM Djoelham Hospital Binjai in 2019. During the anxious state, a person often becomes irritable and easily annoyed due to emotional instability. Also, the patient easily weeps due to helplessness with the problems he is experiencing, causing him to be apathetic and ignore all stimuli coming towards him (Kosasih, 2018). 
The research study, s of Tang, et al (2013) described that stroke patients with anxiety had greater mood disturbance, as shown by their lower scores in the mood domain. It has been reported that mood status is correlated with anxiety in stroke.And also confirmed there is correlation between severity of anxty and occupational limitations. Anxiety conditions can certainly be understood because the limitations of the patient's ability to be disturbed and not a few due to suffering from illness for too long the client will experience anxiety and even panic in response to disturbed basic needs.This statement is in line with the results of the research Kustiawan and Hasriani (2014) that the highest anxiety level of stroke clients is moderate anxiety, which is 28 respondents $(71.8 \%)$ in the Tasikmalaya Hospital. The level of anxiety is caused by various factors, namely in this study influenced by the experience of suffering a stroke for the first time or a second stroke, environmental factors, family support, physical condition, knowledge, belief factors also affect the level of anxiety.

\section{Conclusion}

There is no relationship between social support and anxiety levels in stroke patients with a pvalue $=0.184(\mathrm{p}>0.05)$. It is possible because people during an anxious state often become irritable and easily annoyed due to emotional instability. They easily weep because of their helplessness with their problems, causing them to be apathetic and ignore stimuli coming towards them. Hopefully, future researchers conduct broader research on the relationship between social support and anxiety level.

\section{REFERENCES}

[1] Ananda, Z., \& Darliana, D. (2017). Kecemasan dengan Kualitas Hidup pada Pasien Stroke. Jurnal Ilmiah Mahasiswa, Fakultas Keperawatan, VOl 3 No 3, 1-10. http://www.jim.unsyiah.ac.id/FKep/article/view/4161

[2] Bintari, T. A. Y. U. (2015). Penderita stroke di desa pekuwon kecamatan bangsal.

[3] Blessing, M., \& Oluwagbemiga, O. (2017). Effectiveness of Social Support in Coping with Stroke by Medically Ill Patient in Ibadan. International Journal of Neurorehabilitation, 04(04). https://doi.org/10.4172/2376-0281.1000281

[4] Cookson, C., \& Casey, J. (2013). Social support following stroke. Psychologist, 26(8), 566-569.

[5] Elloker, T., \& Rhoda, A. J. (2018). The relationship between social support and participation in stroke: A systematic review. In African Journal of Disability (Vol. 7). AOSIS OpenJournals Publishing AOSIS (Pty) Ltd. https://doi.org/10.4102/ajod.v7i0.357

[6] Hawari, D. (2016). Manajemen Stres, Cemas dan Depresi. Fakultas Kedokteran Universitas Indonesia: Jakarta.

[7] Hidayati, V. F. (2013). Depresi Pasca Stroke Pada Lansia di panti Wreda Ditinjau Dari Penerimaan Diri Dan Efektivitas Komunikasi Interpersonal. Fakultas Psikologi Universiras Katolik Sowgijaparnata. http://repository.unika.ac.id/10502/1/98.40.2818 vesti fh COVER.pdf

[8] Kosasih, S. dan. (2018). Konsep dan Aplikasi dalam Keperawatan Maternitas. PT Refika Aditama: Bandung.

[9] Kustiawan, R., \& Hasriani, R. (2014). Gambaran Tingkat Kecemasan pada Pasien Stroke 
Iskemik di Ruang V Rumah Sakit Umum Kota Tasikmalaya. Jurnal Kesehatan Bakti Tunas Husada, Volume 12(1), 10-21. https://mail.ejurnal.stikesbth.ac.id/index.php/P3M_JKBTH/article/view/61/61

[10] Mulyatsih, E. (2010). Petunjuk Praktis Bagi Pengasuh dan Keluarga Pasien Pasca Stroke. FK Universitas Indonesia.

[11] Mustika. (2019). Hubungan Dukungan Sosial Keluarga Dengan Kestabilan Emosi Pada Pasien Stroke. Unram Medical Journal, 8(2), 29. https://doi.org/10.29303/jku.v8i2.340

[12] Notoatmojo, S. (2012). Metodologi Penelitian Kesehatan. Yogyakarta: Rineka Cipta.

[13] Shindy, O. W. (2014). Hubungan Antara Dukungan Sosial Keluarga Terhadap Tingkat Self Esteem Pada Penderita Pasca Stroke. Jurnal Psikologi Pendidikan Dan Perkembangan, 3(2), 110-118. journal.unair.ac.id/download-fullpapersjppp1b5b31dac4full.pdf

[14] Tang, W. K., Lau, C. G., Mok, V., Ungvari, G. S., \& Wong, K. S. (2013). Impact of anxiety on health-related quality of life after stroke: A cross-sectional study. Archives of Physical Medicine and Rehabilitation, 94(12), 2535-2541. https://doi.org/10.1016/j.apmr.2013.07.012

[15] Widarti, L. dkk. (2012). Respons Psikologis (Kecemasan dan Depresi) dan Respons Biologis pada Pasien Stroke Iskemik dengan Pendekatan Model Home Care Holistic. Jurnal Ners: Poltekes Kemenkes Surabaya, 7(1), 1-12. https://ejournal.unair.ac.id/JNERS/article/download/3993/2702 